Volume 10, Issue 6, November-December 2019, pp. 45-53, Article ID: IJM_10_06_005

Available online at http://iaeme.com/Home/issue/IJM?Volume $=10 \&$ Issue $=\overline{6}$

Journal Impact Factor (2019): 9.6780 (Calculated by GISI) www.jifactor.com

ISSN Print: 0976-6502 and ISSN Online: 0976-6510

C IAEME Publication

\title{
IMPLEMENTATION OF MARRIAGE BY INDIGENOUS LAW TO YEI TRIBE COMMUNITIES
}

\author{
Julianto Jover Jotam Kalalo \\ Faculty of Law, Universitas Musamus, Merauke, Indonesia
}

Philipus Betaubun

Faculty of Engineering, Universitas Musamus, Merauke, Indonesia

Chyntia Novita Kalalo

Faculty of Teacher Training and Education, Universitas Musamus, Merauke, Indonesia

\begin{abstract}
Yei traditional wedding ceremony is a marriage that holds fast the traditions and customs of the indigenous people. Marriage is a sacred thing in determining a life partner so it must be decided together in the male family. In the implementation of Yei tribal marriages using traditional processions, national law processions, and religious law processions. The Yei tribe has a very thick history and traditional traditions and highly respects their customary law. the process of implementing Yei tribal marriages still uses customary processions combined with religious law so that there is a mixture of the implementation of marriages within the Yei tribal community. The purpose of this study is to study and analyze the implementation of marriage according to customary law in the Yei tribal community. The method used in this legal research is empirical juridical research methods using primary data and secondary data analyzed by descriptive analysis. The results showed that the process of implementing marriages according to customary law in the Yei tribal community is through marriage/application, the marriage process is carried out in a customary manner and then proceed with religion and state, after that it is closed with a custom event / traditional party
\end{abstract}

Keywords: Marriage; Customary law; Society; Yei tribe

Cite this Article: Julianto Jover Jotam Kalalo, Philipus Betaubun, Chyntia Novita Kalalo, Implementation of Marriage by Indigenous Law to Yei Tribe Communities, International Journal of Management, 10 (6), 2019, pp. 45-53.

http://iaeme.com/Home/issue/IJM?Volume=10\&Issue $=6$ 


\section{INTRODUCTION}

Marriage is to legalize the legal relationship between a man and a woman (Salim, 2002). The development of civilization and the advancement of technological science and modernity do not simply remove the customs that live in society. Such processes affect customs, so customs must be able to adapt to the demands of the times so that customs still exist amidst the times.

Pancasila that contains religious values, the value of moral law, the value of natural law, and religious value as legal source material for the positive law of Indonesia. (Inggit et.al, 2017) The culture and rules of Indonesian tribal marriages are not only influenced by cultural customs but are also influenced by religious teachings, such as Hinduism, Buddhism, Christianity, Islam and even influenced by western marriage culture. Therefore, there are many cultures and rules that influence marriage so there are many marriage rules in people's lives. However, there is one thing that becomes the identity of customary marriage, namely its nature which still carries magical values and its sacred nature. This means that in this traditional marriage ceremony there is a braided thread between those who are still alive and their ancestors who are still alive, and with ancestors in the age of eternity. So that the ceremony is held not only for those who are still alive but also for the ancestors (Trianto et.al, 2008). Customary law of marriage is not only an important event for those who are still alive, but marriage is also a very meaningful event and fully received attention and followed by the spirits of the ancestors of both parties (Purwadi, 2005).

Marriage is an indigenous community is one of the sacred and very important events in community life. Marriage is not just an event for the two people who get married but it is a joint family in a bond.

Every ethnic group and ethnic group in Indonesia has and is culturally and socioeconomically bound to the rules and order of traditional values that refer to adat and adat law by harmonizing religious or religious laws. Each ethnic group has very unique traditional ceremonies, as well as marriage ceremonies, in every region in Indonesia has a unique traditional wedding process in each region.

In Papua province, precisely in Merauke Regency, there is a tribe that lives and interacts with nature and utilizes its natural resources and customary territories to survive and carry out its traditional traditions and customary law, the Yei Tribe. The Yei tribe is part of the Customary Law community in the Papua Seasarana region. Customary law communities are groups of people who have ancestral origins, are hereditary in certain geographical areas, and have a system of values, ideology, politics, culture, social and are subject to a system of legal regulations that apply in social life (Kalalo, 2018).

The Yei tribe has a very thick history and traditional traditions and highly respects their customary law. The Yei tribe has a territory between two countries namely Indonesia and Papua New Guinea (PNG). The Yei tribal region is in the part of Indonesia within the administrative area of the Merauke Regency. Yei is geographically a lowland area consisting of savannas, forests and swampy areas. The Yei tribe is one of the tribes in the Merauke Regency. Most of the people are spread out on the border between Indonesia and Papua New Guinea (PNG), especially in seven villages. Namely Erambu, Toray, Poo, Kweel, Bupul, Tanas, and Baidu.

In the case of marriage, confusion often occurs with the adat community itself in terms of following the procedures of the customary marriage procession, Marriage based on Law Number 1 of 1974 concerning marriage, or marriage based on religious law. Intermarriage also brings a dilemma for indigenous peoples, where when inter-tribal marriages occur it is felt that there is no need to carry out traditional marital ceremonies due to different customs, 
so forgetting local traditional ceremonies becomes commonplace which can be replaced by religious marriages and marriages in Civil records.

But sometimes the customary community who still adheres to customary norms governing customary marriages feels that the marriage that is carried out is legal without knowing what the consequences will be if it only takes place customary marriages without following the marriage procedures in the law. Although the Yei tribe has been affected by the State Law marriage system, as well as Marriage based on religion, but customs are still used for the Yei tribal marriage process, the process of implementing the Yei tribal marriage is still using a customary procession combined with religious law so that there is a mixing of the marriage in the community. Yi tribe.

A little explanation above illustrates the existence of the Yei tribe who have customary territories, customary law, strong traditions on the preservation of customary law, especially the implementation of customary law so that the issue of the implementation of Yei community marriage based on customary law becomes the basis of a legal issue writer to study and analyze further on the Implementation of Yei Indigenous Peoples' Marriage based on Customary Law.

\section{METHODS}

The method used in this legal research is empirical juridical research method is a research method that functions to be able to see the law in the real sense and examine how the law works in the community. Because this empirical legal research is researching people in life relationships in society. This research was conducted in Kweel Village, Elikobel District, Merauke Regency. The population in this study was the entire Yei tribe community with samples taken from 1 Kweel Village Chief, 1 Kamp Adat Chairperson. Kweel, 1 guard of a traditional house in the camp. Kweel, and 7 other indigenous people in the camp. Kweel. Sources of Data that can be obtained, Primary data, i.e. data obtained directly from informants/informants studied by conducting observations and interviews directly and secondary data, namely data obtained through observation and study of literature to obtain the theoretical basis, namely by reading various literature related to the research theme. In this study, researchers conducted research by observation and interviews in person. Data obtained or collected in this study both primary and secondary data are qualitative in nature (Mangkoedihardjo, 2010; Samudro and Mangkoedihardjo, 2012; Waremra and Betaubun, 2018; Pratama et al., 2019), so the data analysis technique used is qualitative analysis.

\section{RESULTS AND DISCUSSION}

\subsection{Procedures for Implementing Yei Tribal Marriages According to Customary Law}

Customary law is the rule of human habits in social life. Since humans were revealed by God to the face of the earth, they started their lives as a family, then in a community and then in a state. Since humans have a family they have arranged themselves and their family members according to their habits, for example, the father went hunting or looking for roots for food, then the mother lit a fire to burn prey and then eat together. A habitual behavior that applies continuously so that it is a permanent division of labor (Hardikusuma, 2003). The customary law community has its own culture, traditions, and customs (Kalalo, 2018).

Marriage is a social bond or interpersonal legal agreement that forms a kinship relationship and which is a institution in the local culture that formalizes interpersonal relationships that are usually intimate and sexual. Marriage generally begins and is inaugurated with a wedding ceremony. Generally, marriages are undertaken with a view to 
forming a family. Marriage law is the law that regulates everything related to marriage and all its consequences, divorce and marital property.

In customary law, marriage is living together between a man and one or several women as husband and wife with a view to continuing generations/offspring. According to customary law, marriage is not a private matter of a married person, but also a matter of family, ethnicity, community, and caste. Marriage means separation from their parents and continuing their parents' lifelines. For the tribe, marriage is an effort that causes the tribe to continue in an orderly manner.

For the community (fellowship), marriage is also an important event that results in the entry of new residents who share in having full responsibility for the partnership. For caste, marriage is also important because caste in society often maintains its position by holding an orderly marriage itself. Because this marriage has a very important meaning, its implementation is always accompanied by traditional ceremonies, sometimes complete with offerings. So that the bride and groom survived the new life to the end of their lives or often called life until death. All these ceremonies are transitional ceremonies, ceremonies that symbolize the change in the status of the bride and groom; who used to live apart, after going through the ceremonies came to live together in a family as husband and wife. At first, they belonged to their parents and then became an independent family.

Yei's marriage process consists of marriage, marriage, and traditional events or often referred to as traditional parties.

\subsection{Proposing (Application)}

Customary law gives the term "propose" implies a request which according to customary law applies in the form of a statement of the will of one party to another party for the purpose of establishing marital ties. The proposal includes a preliminary effort in the context of holding a wedding reception (Hadikusuma, 2003).

Basically, marriage has the same meaning in the customary marriage procedures of any ethnic culture, namely the statement of the will of one party to another for the purpose of establishing marriage ties. Proposition or often also called prostitution is a requirement to step into the stage of marriage, both in modern and ancient society it is believed that when a proposal or proposal is a time when making decisions that are very important for the lives of their children, at this stage also determined that the applicant is accepted or rejected. So that the stage of marriage is a very important start in the management of marriages in indigenous peoples who have several terms and conditions for marital descent, family, and kinship.

In the application procedure for Yei people, there are several conditions and rules that must be implemented, namely:

\subsubsection{Application Process}

Candidates are conducted by men to women. Candidates can also only be done by male families to female families that have been chosen by male relatives.

The marriage in the Yei tribe is very identical with the traditional traditions that they hold for generations, it can be seen in the process of hosting this can only be done by the men, here the women can only wait from the men to declare the intention to get married. On the other hand, what is more, unique is that the bride-to-be to be married to the bride-to-be is chosen by male relatives so it is not from the bridegroom who chooses the bride-to-be. It can be seen that the prospective bridegroom is passive, who are active in finding a prospective bridegroom's spouse are relatives of the bridegroom. Unlike in general, the process of marriage is based on the existence of interest or a close relationship between a man and a 
woman if in the Yei tribe there is an interest in the male relatives of the prospective bridegroom to the woman and proposed by the male family. man

\subsubsection{Process of Submission}

In the process of applying in the Yei Tribe in general, it must bring surrender or delivery of property to the bride. The offerings must be brought by the bridegroom in the form of objects or other items that are considered sacred and are traditions that must exist in the application process. Objects or items that must be carried are wati, betel and leaves, whiting, and areca nut. These objects are based on the customary traditions of the Yei tribe, which form the binding agreement.

According to Mr. Egenius Beljai who is the Chief of the Yei Tribe Custom in the Kweel village, it is different from the adat proposal nowadays, which is more modern now using some amount of money, and some even do the proposal without matchmaking by parents as if it is required. He said that with the advancement of the world of law and technology quite a lot of people who did not follow the habits of their parents and ancestors by behaving like modern society. For example, a proposal should be done when parents who have sons want a daughter they know and have determined to have an arranged marriage to, but their sons have made their own choices. The thing that is very worried about the choice of children is finding a woman who has the same caste or lineage, in other words, relatives.

Based on the explanation above the proposal is a customary tradition in the Yei tribe and becomes the core of the introduction of the family, both the female family and the male family are united in a large family bond between the groom and the bride. In addition, it is also the basis for terminating whether a marriage is permitted between the bridegroom and bride. Thus the application process is a process that is very important in the implementation of marriage within the Yei tribe.

\subsection{Marriage}

Marriage is a necessity in the life of a human being. Where a man and woman live a life together that embodies the unity of their respective households in life as husband and wife. The life together, which is called marriage, has certain legal consequences if the relationship is legal according to the law after going through procedures determined by the rules of law. According to customary law in general marriage in Indonesia not only brings consequences to civil relations, such as the rights and obligations of husband and wife, shared property, the position of children and the rights and obligations of parents but also concerns the customs, family, kinship and kinship relations. and concerning traditional and religious ceremonies. In indigenous communities, marriage is not only a civic engagement but is also a customary engagement and at the same time a kinship and neighborhood engagement (Hadikusuma, 2007).

Marriage has the main goal to give birth to offspring. Therefore, the marriage legal system or marriage system is determined by the way of drawing a lineage, there are two kinds of ways to draw a lineage, namely Unilateral and Bilateral. Starting from this, the marriage system also has two types, namely: marriage in a unilateral society whose system is exogamy; marriage in bilateral societies whose marital system is not bound by the necessity for exogamy. What is meant by an exogamy marriage is a marriage in which the parties to the marriage must have a clan member that is not the same.

In marital procedures in the indigenous tribe of $\mathrm{Yi}$, there are two marital systems, namely: 


\subsubsection{Yei Traditional Marriage by the Yei Tribe}

The family structure used by the Yei tribal community is the family structure seen from the patrilineal line. In the patrilineal family structure, the main thing about this marriage is to give "honest" by the man to the woman as a symbol of the severance of the wife's family relationship with her parents, ancestors and in short with her relatives and fellowship. After marriage, the wife enters the husband's family environment as well as his offspring children. This honest system is not necessarily then understood as understood by western ethnologists as "buying" but in accordance with the understanding of pure traditional law ethnologists, then honesty is a "replacement" understanding that the girl's position in the religio-magicalcosmic sense, replaced by an object so that the balance is maintained, not empty the meaning of religio-magical-cosmic.

Honest marriage contains three aspects of understanding, namely on the juridical side there will be a change in status, on the social (political) side, the marriage will strengthen relations between relatives, family relations and eliminate hostility while the third is the economic side of the exchange of goods

In the Yei tribe, there are two (2) castes or lineages namely 'Eagle' and 'Nak', this caste is the benchmark or concern of parents for their children in choosing a partner. In the matchmaking rules as discussed in the first stage, a boy from the "Lang" caste cannot marry a girl from the "Lang" caste itself, then this explains that the system adopted is the exogamy system (married out). The stages of the traditional Yei tribal wedding ceremony are:

"Customary marriages can take place in a traditional house if there is a traditional house in the neighborhood, but if nothing can be done in the yard or church that will validate the couple's national marriage," said an expression from Mr. Stephanus Bajai as the guard of the traditional house in Kweel village.

Mr. Egenius also explained the stages of the customary marriage procession that were ready to be carried out before sunrise, because for the people of the sun is the creator, who will witness a new couple who will marry and be sealed with whiting. Community search equipment is also used at traditional wedding ceremonies as a binder, men holding bows and women holding wood commonly used to beat sago fronds in making kitchen food, the two work tools are linked to each other and walk towards the church on condition that the mother of the men a man prepares a new sago frond that will be stamped on by two children as a symbol of a mother's craft that takes care of a boy until adulthood and it is hoped that his sonin-law can follow the 'craft' of his mother-in-law in caring for their husband and children.

Clothing worn during marriage ceremonies is custom clothing and attributes. When a marriage ceremony or other ceremony, traditional clothes wore the same. In the customary rules, if a boy wants or will marry a girl from another tribe, the condition of the custom is that the daughter must follow and obey the applicable customary law of Yei. So that the marriage ceremony process is considered valid in customary law.

\subsubsection{Religious Marriage by the Yei Tribe}

In Emile Durkheim's terms, religion can deliver individual members of society into social beings. Religion preserves society preserves it before humans in the sense of giving value to humans, instilling human nature for Him. In the rite of worship, the community reaffirms itself in symbolic deeds which manifest its attitude, thereby strengthening the community itself. Meanwhile, the rite itself is a means for social groups to periodically re-establish themselves (Narwoko et.al, 2004).

Yei people have long followed the religious law, in the identical research village adheres to Christianity, the religious law that entered after the Dutch colonialism ended, brought 
considerable influence, but it did not become a stumbling block to the customs that lived in the community.

Religious rituals or traditions that have a function in people's lives will last a long time and will not be easily lost, as said in the axiom of functional theory that everything that has a function will not easily disappear by itself, because since the past until now it still exists, has a function and even portray a number of functions (Soelaeman, 1995).

Since the time of ancestors, Yei tribal marriages have been arranged to carry out customary marriages before entering the church blessing ceremony, so that after the traditional wedding ceremony is held, the bride and groom are directed side by side with bows and wood that bind the bride and groom to the church and then receive the marriage blessing, after the church blessing ceremony is over, the bride and groom still continue with the traditional program.

In this society the level of awareness of church marriages is very high because it has long been adhering to the teachings of religion, even now the existing churches and customs are running side by side for marital affairs. The church will reject a couple who have not been traditionally approved, and postpone the marriage that has been registered for a religious marriage.

\subsection{Indigenous Events / Indigenous Parties}

Customary events or often also referred to as traditional parties are one of the traditions of traditional communities that are still considered to have values that are still quite relevant to the needs of indigenous peoples in a certain area. Apart from that as a human effort to be able to relate to the spirits of the ancestors, it is also a manifestation of the ability of humans to actively adjust to nature or their environment in a broad sense. The adat program is closely related to the traditional rituals of a data legal community that still adheres to its traditional traditions and laws.

The relationship between nature and humans is a necessity that cannot be denied because the relationship has very high sacred values. This is expressed in the mystical personification of natural forces, namely belief in supernatural beings, belief in creator gods, or by conceptualizing relationships between various social groups as relationships between animals, birds, or natural forces (Keesing, 1992).

Religious rituals carried out by the community are based on the beliefs held by the community, this kind of trust encourages people to perform various actions or actions aimed at seeking contact with the supernatural world of the ruler of nature through rituals, both religious ceremonies and rituals other customs that are felt by the community as critical moments, which can bring magical danger, misery and disease to humans and plants (Koentjaraningrat, 1985).

The implementation of traditional ceremonies and religious rituals that are based on the existence of supernatural powers are still carried out by some groups of people in Indonesia, whether in the form of death rituals, thanksgiving or slametan rituals, rituals to reject reinforcements, ruwatan rituals, and so forth (Marzuki et.al, 2015). These rituals have become a tradition and become part of the daily life of most people because they have been passed down from generation to generation by their ancestors to the next generation.

This process applies to families who carry out the event, the traditional party in general is a thanksgiving that the bride and groom have been united, so that at the traditional party 'Nggatzyi' ceremony, the traditional ceremony of burning the stone and playing 'zyi', the time brought when applying and ceremonies the marriage will be used at this time by the traditional elders, for the stone-burning ritual which is the making of traditional food that is 
'Sep' will be eaten by all participants of the traditional party without exception, in this ceremony those present who take part in eating are witnesses rather than the bride is legal.

\section{CONCLUSION}

The implementation of marriage according to customary law in the Yei Tribe community consists of marriage or application, traditional wedding ceremonies, religious marriages, and traditional ceremonies. According to customary law in general marriage in Indonesia not only brings consequences on civil relations, such as the rights and obligations of husband and wife, shared property, the position of children and the rights and obligations of parents but also involves the relations of customs, family, kinship, and neighborliness. and concerning traditional and religious ceremonies. In indigenous communities, marriage is not only a

Civil engagement but is also a customary engagement and at the same time a kinship and neighborhood engagement.

\section{REFERENCES}

[1] Roger M. Keesing, Antropologi Budaya: Suatu Perspektif Kontemporer. Bandung: Erlangga, 1992

[2] Andi Bau Inggit AR, A. Pangerang Moenta, Marwati Riza, Hamzah Halim, "Local Regulation Review in Realizes Legal Order of the Local Governance". Journal of Law, Policy and Globalization, ISSN 2224-3240 (Paper) ISSN 2224-3259 (Online), Vol.59, 2017

[3] Hilman Hadikusuma, Pengantar Ilmu Hukum Adat Indonesia, cet. ke-2. Bandung: Mandar Maju, 2003

[4] Hilman Hadikusuma., Hukum Perkawinan Indonesia menurut Perundangan, Hukum Adat, Hukum Agama. Bandung: CV. Mandar Maju, 2007

[5] Julianto Jover Jotam Kalalo, Politik Hukum Perlindungan Hak Ulayat Masyrakat Hukum Adat di Daerah Perbatasan. Makassar: Disertasi Universitas Hasanuddin, 2018

[6] Julianto Jover Jotam Kalalo, Protection of Indigenous Legal Community Rights in the Border Area of the South Papua, International Journal of Mechanical Engineering and Technology, 9(12), 2018, pp. 212-219.

[7] Koentjaraningrat. Pengantar Ilmu Antropologi. Jakarta: Aksara Baru, 1985

[8] Mangkoedihardjo, S, Individual or communal sanitation services?: Decision based on wastewater storage capacity. Advances in Natural and Applied Sciences 4 (3), 2010, 226228.

[9] Marzuki, Nur Najman, Simbolisme Dalam Upacara Adat: Kajian Terhadap Upacara Adat Mappogau Hanua Pada Masyarakat Adat Karampuang di Kabupaten Sinjai, Sulawesi Selatan, Tesis, Sekolah Pasca Sarjana: Universitas Gajah Mada, 2015

[10] Narwoko, J. Dwi dan Bagong Suyanto, SOSIOLOGI: Teks Pengantar dan Terapan. Jakarta: Kencana, 2004

[11] Nasra Pratama, Fransiskus Xaverius Manggau, Philipus Betaubun, Attitude Quadrotor Control System with Optimization of PID Parameters Based On Fast Genetic Algorithm. International Journal of Mechanical Engineering and Technology, 10(1), 2019, 335-343. 
[12] Purwadi, Upacara Tradisional Jawa, Menggali Untaian Kearifan Lokal. Yogyakarta: Pustaka Pelajar, 2005

[13] Richard S. Waremra and Philipus Betaubun, Analysis of Electrical Properties Using the four point Probe Method. E3S Web of Conferences 73, 13019, 2018

[14] Salim H. S, Pengantar hukum Perdata Tertulis (BW). Jakarta: SInar grafika, 2002

[15] Samudro, G. \& S. Mangkoedihardjo, Urgent Need of Wastewater Treatment Based on BOD Footprint for Aerobic Conditions of Receiving Water. Journal of Applied Sciences Research 8 (1), 2012, pp 454-457.

[16] Soelaeman, M. Munandar, Ilmu Sosial Dasar: Teori dan Konsep Ilmu Sosial. Bandung: PT ERESCO, 1995

[17] Trianto dan Titik Triwulan Tutik, Perkawinan Adat Wologoro Suku Tengger, (Jakarta: Prestasi Pustaka, 2008 